Article

\title{
Understanding Consumers' Loyalty to an Online Outshopping Platform: The Role of Social Capital and Perceived Value
}

\author{
Yumei Luo ${ }^{1}(\mathbb{D})$ and Qiongwei $\mathrm{Ye}^{2, *}$ (i) \\ 1 College of Business and Tourism Management, Yunnan University, Kunming 650021, China; \\ luoyumei@ynu.edu.cn \\ 2 Business School, Yunnan University of Finance and Economics, Kunming 650500, China \\ * Correspondence: yeqiongwei@163.com; Tel.: +86-871-65023555
}

Received: 14 August 2019; Accepted: 26 September 2019; Published: 28 September 2019

\begin{abstract}
We draw upon the social capital theory in order to discuss how three dimensions of social capital affect consumer value and loyalty to online outshopping platforms. After considering the characteristics of consumers, we propose that the structural, relational, and cognitive dimensions of social capital promote consumers' perceptions of utilitarian and idea shopping value, and that those perceived values increase loyalty to online outshopping platforms. The survey data of 291 Chinese consumers with online outshopping platform experience are used to test the model. The results show that different dimensions of consumers' social capital influence their loyalty through different values. Utilitarian value mediates the effects of structural capital and cognitive capital on loyalty, whereas hedonic value (ideal shopping value) mediates the effects of structural and relational capital on loyalty.
\end{abstract}

Keywords: social capital; international online outshopping; utilitarian value; hedonic value; loyalty

\section{Introduction}

International online outshopping (IOO) refers to consumers buying products and services across borders over the Internet with the click of a button [1,2]. Young people tend to favor IOO for cross-border online shopping. According to iiMedia Research, 41 million Chinese were IOO shoppers in 2016, and their numbers were expected to reach 74 million by 2018. Realizing the opportunities in international e- and m-commerce, numerous online marketplace companies operate shopping platforms to provide opportunities for consumers to purchase foreign products from foreign websites (e.g., Xiaohongshu, VIP International, Amazon Global, Kaola.com, Ymatou, Tmall.HK, and JD.HK). Establishing and maintaining consumer loyalty determines whether IOO platforms in China will survive and develop sustainably. "Loyalty" refers to the affirmative recollections that prompt consumers to revisit an IOO platform or repurchase products or services online [3]. Few studies have examined loyalty to IOO platforms and, at that, have investigated, for the most part, domestic Consumer-to-Consumer (C2C) [4], domestic Business-to-Consumer (B2C) [5,6], and offline IOO platforms [7,8].

Loyalty to an IOO platform differs from loyalty to a domestic $\mathrm{B} 2 \mathrm{C}$ or $\mathrm{C} 2 \mathrm{C}$ platform because cross-border shoppers are brand-oriented, fashion-conscious, and expressive about foreign products and outshopping $[9,10]$. Boeuf and Sénécal [2] have indicated that IOO consumer behavior is likely driven by additional or distinct determinants. The experience of online outshopping differs from domestic online shopping (e.g., B2C or C2C) because it involves, in part, the international components of consumption (e.g., costs of shipping and customs, foreign language, well-known foreign brands) [1]. Moreover, it differs from offline outshopping in that it does not consider any physical travel that might 
affect the ease and simplicity of the purchase, as well as the role of trust in the retailer [2]. Therefore, it is plausible that factors influencing loyalty to an IOO platform differ from factors influencing loyalty to other platforms (e.g., domestic B2C or C2C, offline outshopping). Safari and Thilenius [11] investigated consumers' specific uncertainties when purchasing from foreign e-tailers. Wagner et al. [12] empirically indicated that consumers' online outshopping intentions are particularly affected by specific benefits (e.g., exclusive brands/products and a wide selection) and risks (e.g., long delivery times, additional fees, and warranty claims), while Boeuf and Sénécal [2] described six factors that may affect online shopping intentions. In sum, the literature further indicated that IOO differs from domestic online shopping.

The existing research on IOO mainly focuses on the consumer's online intention or purchasing - or not purchasing-behavior, rather than repurchasing behavior or loyalty. The research on loyalty in the context of IOO is scarce. Thus, we conceptualize and empirically analyze the antecedents of this behavior. Research indicates that consumers' perceptions of value with respect to online shopping can foretell their loyalty. Perceived value comes from perceived benefits [13] and is the ultimate motivation of consumer behavior [14]. Empirical studies have confirmed the relationship between consumers' perceived value and loyalty, and have conceptualized perceived value as a multidimensional construct (e.g., utilitarian and hedonic values) $[15,16]$. Thus, we examine whether consumers' utilitarian and hedonic shopping values influence their loyalty to IOO platforms. Based on IOO consumers' characteristic pursuit of affordability, brand, fashion, and innovation, we consider idea shopping value type of hedonic shopping value. Idea shopping is to keep up with the trends and new fashions and see new products and innovations [4].

Cross-border shopping entails risks (e.g., product quality, refund policy, and language barriers) [17]. IOO platforms need to reduce perceived risks and raise perceived value. The ability to post online reviews and recommendations boosts consumers' social capital and consumption on the IOO platforms. According to a report from iiMedia, $73.5 \%$ of Chinese IOO shoppers had shared experiences on platforms or with friends in 2016, and that $62.1 \%$ respect product reviews [18]. Drawing on actor network theory, Zahedi and $\mathrm{Lu}$ [19] claimed that online community platforms offer personalized social network services that help consumers make decisions and construct personal network ties. Empirically, social capital can be converted to economic or other advantages [20], reducing transaction costs [20] and increasing enjoyment of social interactions [21]. However, previous studies have rarely examined how consumers' social capital affects the value they perceive, especially in the context of IOO platforms.

To fill these gaps in the literature, we draw upon theories of social capital and perceived value, consider the characteristics of IOO consumers, and propose that consumers' social capital and perceived shopping value influence consumer loyalty to IOO platforms. We examine how the structural, relational, and cognitive dimensions of social capital influence consumers' perceived value [6]. Further, we assess how perceived value affects consumers' loyalty to IOO platforms.

This research represents a relatively unexplored area in the context of IOO and it will enrich existing studies of consumers' online shopping and offline outshopping. The results of this study will also help professional marketers to arrive at a broader theoretical understanding of the drivers of consumers loyalty to IOO platform. The results will provide important guidelines for building loyalty to IOO platforms through perceived shopping value, as well as for the formulation of social strategies that encourage consumers to actively engage in online communities on IOO platforms. Ultimately, understanding why and how consumers revisit or repurchase products on IOO platforms can help businesses to stay competitive in the global market.

\section{Literature Review}

\subsection{Perceived Value}

First-time and repeat customers have separate motives for accessing IOO websites. Experienced customers better comprehend and evaluate information and update their evaluation criteria [22]. Means-end chain (MEC) theory establishes a theoretical connection between consumers' perceived 
values and continuance behavior. According to Gutman [14], MEC has three levels of cognitive abstraction: attributes, consequences, and values. Values ultimately motivate consumer behavior. In other words, consumer behavior is value-driven. Therefore, it is reasonable to directly correlate customers' perceived shopping value and continuance shopping. Empirical studies have confirmed this correlation $[4,10,21]$.

Perceived value refers to the consumer's comparison of a product's cost and quality [23]. Walter et al. [24] defined it as a tradeoff between multiple benefits and sacrifices. Liljander and Strandvik [25] adopted perceived benefits and perceived prices. Afuah [26] regards value as a function of the extent to which it contributes to customers' utility or pleasure. Although operationalization differs, the consensus is that perceived value has two dimensions: utilitarian value and hedonic value [27-30]. Utilitarian value is the functional, goal-directed, and rational reason for using a product or service. Hedonic value is the multisensory, novel, fantastical, and emotive aspect of shopping [31]. Arnold and Reynolds [32] cite six dimensions of hedonic value: adventure, social, gratification, idea, role, and value.

Hedonic and utilitarian attributes together capture the essence of products and services and are understood consistently across disciplines. Instances include the hedonic and pragmatic quality of human-computer interactions [33], the perceived usefulness and enjoyment of accepting a technology [34-36], and the extrinsic (i.e., perceived usefulness) and intrinsic motivation (i.e., perceived enjoyment, playfulness, and flow) in self-determination theory $[37,38]$. All consumption involves utilitarian and hedonic values $[13,15,31,39-42]$, and both drive consumer loyalty $[13,43,44]$.

We surmise that perceived utilitarian and idea shopping value (a subcategory of hedonic value) directs consumer loyalty. In the context of IOO, consumers' shopping involves seeking the benefits of convenience, broad product offering, and monetary savings, and so on, which are the most common reinforcers of online shopping with utilitarian value $[6,40,45]$. Fashion consciousness and perceived expressiveness towards foreign products also influence consumers' international outshopping behaviors $[9,10]$. Finding, assessing, and appreciating new trends, brands, product launches, and pre-launching information through online stores as idea shopping value also influence consumers' online shopping behaviors [4]. IOO platforms serve idea shopping because they keep abreast of trends and showcase new products.

\subsection{Social Capital Theory}

Social capital refers to "the sum of the actual and potential resources embedded within, and derived from, the network of relationships possessed by an individual or social unit" [46] (p. 243). Social capital is the resources embedded in social networks [47]. Coleman regards social capital as a personal resource acquired through social networks. Interpersonal communication leads to information exchange and generates intragroup goals and expectations. Luo et al. [48] called social capital a common resource of groups that should serve group interests. Putnam [49] suggested that social capital is a feature of organizations that improves trust among members and prompts reciprocal behavior.

Social capital has three dimensions: structural, relational, and cognitive [46]. Structural capital pertains to the integrity of a social network-it is a pattern of interactions among individuals and organizations that reflects ties between people and units [50]. Relational capital refers to relationships people form over long-term interactions. These relationships affect behavior and facilitate social contact, identity, and reputation [46,51]. Cognitive capital embodies shared languages, rules, and modes of expression that reduce communication barriers and cost, as well as spread understanding. Shared language, a major instantiation of cognitive capital, emphasizes the common terms, communication patterns, and narrative forms used in communicating [51], and facilitates the formation of common goals [52]. To summarize the work of Sun et al. [51] and Huang et al. [4], structural capital manifests as social interactions, relational capital as mutual trust, and cognitive capital as shared language.

In organizational settings, previous studies have found that social capital facilitates coordination and cooperation for mutual benefit [53]. Tsai and Ghoshal [52] empirically demonstrated that social capital facilitates information exchange. In young technology-based firms, Yli-Renko et al. [54] 
examined the relationship between social capital and knowledge exploitation. In virtual communication, Wasko et al. [55] and Chang and Chuang [56] verified that social capital affects knowledge-sharing. Chen and Lu [57] argued that, in social networking services, a user's relational capital sustains their commitment and participation. Lee et al. [58] hold that social capital creates perceived social, experiential, informational, and transactional value. Per Piyathasanan et al. [59], social capital is a communal experience that elevates perceived economic and social values and influences customer loyalty in a virtual environment. Zhang et al. [60] indicated that social interaction can positively influence social, information, and hedonic value, and that only social value and hedonic value lead to high continuance intention to use WeChat. Social interaction ties can positively influence online community users' participation intention [61,62]. Hossain et al. [63] found that social capital significantly and positively influences electronic word-of-mouth (eWOM) communication. Furthermore, some studies explored the impact of social capital on online shopping platform. Huang et al. [4] indicated that social capital between buyers and sellers (i.e., cognitive, structural and relational capital) positively influence online buyers' satisfaction and loyalty on $\mathrm{C} 2 \mathrm{C}$ platforms. For business-to-business transactions, Zahedi et al. [64] used a critical realism approach to identify constructs salient to vendors-exchange relationships, and found that trust as social capital contributed to the perceived value of cooperative relationships. Most studies of B2C platforms focus on the influence of the social relationship between consumers and retailers (i.e., trust) on consumers' repurchase intention [65-67]. However, few studies have addressed social capital between consumers. In this study, we consider the social capital among consumers because sharing and communication among consumers on IOO platforms is more important to help consumers make decisions and reduce risks.

On IOO platforms, consumers form social capital through mutual sharing and the communication of goods, businesses, and shopping experiences. Structural capital embodies patterns of consumers' connections on the IOO platform, and is operationalized as opportunity, as well as frequency and intensity of communities. Trust and shared language among consumers on the IOO platform constitute consumers' rational and cognitive capital, respectively. In that regard, IOO resembles domestic e-commerce platforms, and abundant research has shown that social capital formed there affects consumers' perceptions of value, and thus loyalty. For instance, Yang and Zhou [68] discovered that visual social capital influences users' perceptions of information value, and thus purchasing decisions. Studies based on the stimulus-organism-response paradigm have proposed that social interaction on websites affects consumers' perceptions and emotional involvement [69], pleasure [70], and flow experience [71,72] which, in turn, promote purchasing behavior. We consider that social capital formed by consumers on IOO platforms promotes their perceived value and thus increasing their loyalty.

\subsection{Customer Loyalty}

Early studies of consumer loyalty were grounded on such behaviors as repeat consumption and continued use. Later research found that behavior does not differentiate real from false loyalty, and emotional factors entered the literature. Researchers surmised that positive attitudes precede repeat consumption. According to Oliver [73], combining considerations of loyal behaviors and loyal attitudes has attracted scholarly recognition and acceptance [74,75].

Researchers generally agree that customer loyalty follows traditional rules and e-networks and traditional businesses can measure it as behaviors and attitudes. For example, Gruen et al. [76] interpreted repeat purchases and online endorsements as proxies for brand loyalty in the e-business era. Nonetheless, traditional and e-network environments differ. First, the Internet breaks geographical and time constraints, and expands the choice of products and services. It lowers switching costs, making it harder for firms to cultivate and maintain loyalty. Second, notions of what constitutes loyalty to a website have changed. Corstjens and Lal [77] believe, for instance, that it is repeat visits and repeat consumption of different products. Gefen [78] defined online loyalty as consumers returning to a website for additional purchases. Srinivasan et al. [79] stated that online loyalty is a consumer's preference for a retailer that leads to repeat purchases. Third, loyalty to websites differs from loyalty to 
brands. In an e-network context, information technology tailors information for online consumers and further facilitates cognitive loyalty. We define consumer loyalty to IOO websites as repeat visits, positive recommendations, and repeat purchases.

Studies of what influences loyalty on e-networks emphasize characteristics of consumers, products/services, sellers, and websites [80]. They include consumer satisfaction [81], trust, and commitment, an awareness of a website's value, and switching costs. Other factors include product/service quality, discounts/rewards, and quantity, as well as sellers' reliability and high-quality support, website interactivity [82] and ease of use, content and selectivity of product/service, interface friendliness, system quality, personalized service, and service quality $[83,84]$. In this paper, we focus on the linkage between perceived value and loyalty. Scholars have long studied this relationship for real-world products and services [42] and the virtual community [59,60], but few have considered it in IOO platforms. In addition, Chaston and Mangles [85] and Toufaily et al. [80] proposed that, apart from transactions, a website's social functions are most salient to its competitiveness. Therefore, we examine how relation-based factors affect loyalty.

\section{Hypothesis and Model}

\subsection{Structural Capital and Consumers' Perceptions of Value}

Structural capital embodies patterns of human connections [46]. In visual communication, the intensity of network relations, time spent, and frequency of communication comprise social ties [86]. Structural capital influences consumers' perceptions of value through acquiring resources and enabling people to share and apply information. Social capital theory suggests that social ties, a dimension of structural capital, bind people and stream information and resources [46]. The strength of ties can be measured by time, emotional intensity, and intimacy [66]. We argue that structural capital is operationalized as the intensity of relationships, opportunity to communicate, and frequency of interactions among online consumers.

The structural dimension of social capital reduces the time and effort needed to collect information by opening informational channels [56]. Social interconnectedness strengthens informational exchange and bestows cost-effective access to information while avoiding false expectations for transactions. Consumers perceive utilitarian value when there is no discrepancy between their experience of, and their expectations for, a product and the shopping process. They believe that information on the IOO platform helps them to align their choices and expectations. Socially interactive connections help consumers to share and receive information about products, their promotion, quality, and relevance to personal needs. Thus, structural capital not only enriches product information, but also reduces the costs of searching and purchasing.

\section{H1. Structural capital enhances IOO consumers' utilitarian value.}

Social interconnectedness helps consumers pursue "fashion". IOO consumers seek fashion and novelty and become dissatisfied if life curtails their experience of acquiring "more things". Interconnectedness accelerates the sharing of information [86] and other consumers' access to "new" products and "fashion", thus affecting consumers' perception of fashion value. At the same time, the pursuit of "fashion" presents symbolic features, and interconnectedness helps consumers to become leaders of fashion consumption. Socially interconnected consumers more easily consult others on the IOO platform and derive the psychological satisfaction of becoming fashion leaders. Therefore, we propose:

H2. Structural capital enhances IOO consumers' idea shopping value. 


\subsection{Relational Capital and Consumer Perceptions of Value}

Relational capital describes interpersonal relationships [46]. One dimension of relational capital, [87,88], trust, is essential for Internet communities [89], where it is constructed through virtual interactions that create perceptions of members' abilities, benevolence, and integrity [90]. In an atmosphere of trust, consumers are more likely to offer responsible contributions, accept information from others, and perceive more value in informational resources [91]. Mutual trust provides consumers more objective and accurate information and aid-in this way, they can spend less effort understanding information about goods and sellers before buying, and more options to make more accurate choices to promote their perceived utilitarian value. We propose the following:

H3. Relational capital enhances IOO consumers' utilitarian value.

Trust facilitates communication between consumers and enhances their confidence across IOO platforms, so they enjoy shopping and more willingly share experiences. Consumers' pursuit of novelty may engender social disapproval, but trust among consumers reduces and promotes the pursuit of fashion. Therefore, we propose:

H4. Relational capital enhances IOO consumers' idea shopping value.

\subsection{Cognitive Capital and Consumers' Perceptions of Value}

Cognitive capital includes resources through which people in social networks share interpretations $[48,89]$. Shared cognitions strengthen people's appraisal and understanding of each other and improve perceived value by reducing the effort required to understand each other [51]. Meaningful exchange requires a shared language. Shared language includes norms, standards and assumptions [92], which are dimensions of cognitive capital. By facilitating understanding, shared language impacts the transfer and understanding of information [93], thereby enhancing relations among participants and information sharing [94]. Nahapiet and Ghoshal [46] declared that shared language is beneficial for members to communicate, access information, improve common understanding of the benefits of information-sharing, and facilitate informational combination and exchange.

A shared language enables consumers to combine product and shopping information, avoid misunderstandings in communication, and to share resources without barriers [51]. Common understanding raises awareness of information from fellow consumers and provides further valuable information. Cognitive capital promotes mutual understanding and strengthens communication, which reduces the effort required to obtain information about product quality and price. This bolsters the perception of utilitarian value.

H5. Cognitive capital enhances IOO consumers' utilitarian value.

In addition, shared language contains information that facilitates sharing "new" products and "new" ways to pursue "fashion". We propose:

H6. Cognitive capital enhances IOO consumers' idea shopping value.

\subsection{Perceived Value and Loyalty}

As motivational constructs, values serve as standards or criteria that guide the selection and evaluation of actions and things. Thus, consumers' perceived values are the highest goals in the MEC hierarchy. They motivate and direct customer behavior and decisions [14]. Repeat purchases are primarily based on value judgments of whether a past consumption experience helped consumers to achieve their goals [6]. 
According to Wolfinbarger and Gilly [95], hedonic and utilitarian motivations guide the behavior of online shoppers [41]. Hong et al. [30] revealed that utilitarian and hedonic values affect consumers' intention to continue buying Smartwatches. Oghuma, et al. [96] showed that perceived usefulness (a utilitarian factor) and perceived enjoyment (a hedonic factor) affect users' intentions to continue using mobile instant messaging. Fang et al. [97] and Chiu et al. [6] illustrated that perceived utilitarian and hedonic values influence online shoppers' repurchase decisions. Evidence has revealed that utilitarian value is an extrinsic motivation for the effective use of IT [98-101]. Hedonic value (perceived playfulness and enjoyability) as an intrinsic motivation determines users' intentions to continue [102-105]. In addition to pursuing quality and price, IOO consumers seek "fashion" that brings them satisfaction in pursuing novelty, thus bringing consumers the recognition of fashion consumption and the pleasure of free choice in the consumer experience, all of which impact consumer loyalty. Therefore, we propose:

H7. Utilitarian value influences loyalty to IOO websites.

H8. Idea shopping value influences loyalty to IOO websites.

We model IOO consumers' perceptions of value through the lens of social capital. We argue that social capital generates utilitarian and hedonic value. It generates utilitarian value by reducing transaction costs and elevating shopping convenience [20]. Social capital boosts positive social outcomes of fashion consuming, such as improving idea shopping. In turn, consumers' perceptions of value affect their loyalty to the IOO platform. Figure 1 illustrates these hypotheses.

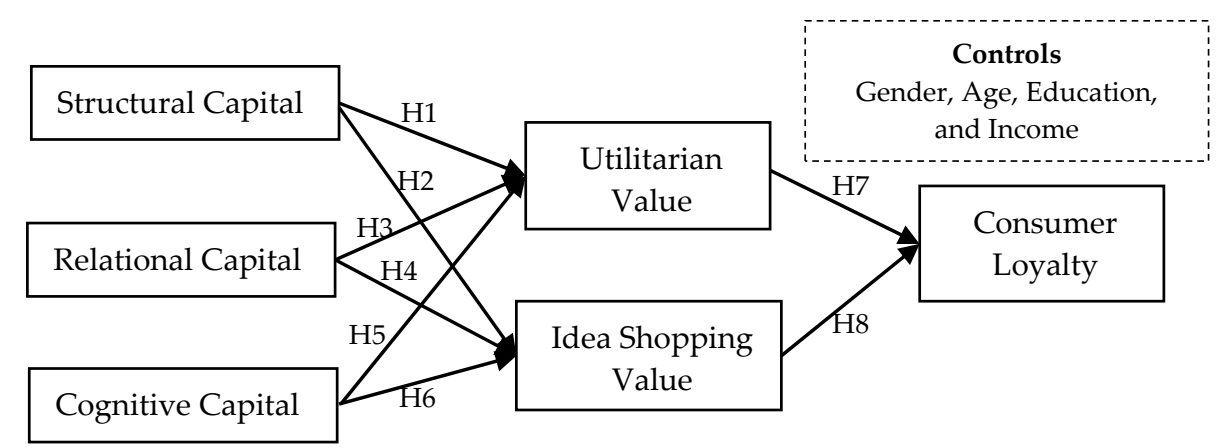

Figure 1. Research Model.

\section{Research Design}

\subsection{Measurement and Data Collection}

We measured six constructs adapted from previous studies. Scales of consumer loyalty are from Gefen [78], and items denoting the three factors of social capital are adapted from Chiu et al. [86]. We measured utilitarian value and idea shopping per Chiu et al. [6]. Age, gender, education, and income are control variables. Most items were initially in English-we translated them into Chinese and modified them for easier comprehension. All the items use a seven-point Likert scale spanning 1 (strongly disagree) to 7 (strongly agree). Using the seven-point Likert scale captures more differences and has better validity. Appendix A describes the items.

\subsection{Data Collection}

We tested our model with samples collected from an online survey by Sojump (http://www.sojump. com), China's premier online survey service. Considering the objective of our research is consumers' loyalty on IOO platforms, we required the respondents who were consumers with IOO experience. The IOO platforms include Kaola.com, Meilishuo Hugo, Ymatou, Xiaohongshu, Tmall.HK, Amazon 
Global, JD.HK, and VIP International because these IOO platforms are popular in China. Sojump was chosen because it can assure respondents' variety and quantity, and we can confirm that our sample interviewees have experience in using the Internet and an online questionnaire. Sojump randomly selected 409 experienced consumers with IOO and released questionnaires to them.

Before the respondents filled in the questionnaire, the research objectives were explained to them and they were asked whether they had engaged in online outshopping before. If no online outshopping experience was reported, it was suggested they did not participate in the rest of the study. If they had online outshopping experience, they were asked to choose one IOO platform they often used from the list of multiple IOO platforms (e.g., Kaola.com, Meilishuo Hugo, Ymatou, Xiaohongshu, Tmall.HK, Amazon Global, JD.HK, and VIP International), and then complete the rest of the questionnaire based on the platform of their choice.

To ensure validity, we deleted incomplete responses, responses having identical answers, and questionnaires completed in a suspiciously brief time. Overall, 291 valid and complete questionnaires were retained for data analysis. Therefore, the percentage of valid responses out of all responses was $71.2 \%$. Table 1 shows respondents' demographic characteristics.

Table 1. Sample Demographics ( $=291)$.

\begin{tabular}{cccc}
\hline Measure & Items & Frequency $\mathbf{( N ~ = ~ 2 9 1 ) ~}$ & Percentage \\
\hline \multirow{2}{*}{ Gender } & Male & 116 & 39.9 \\
& Female & 175 & 60.1 \\
\hline \multirow{5}{*}{ Age } & $<25$ & 38 & 13.1 \\
& $26-30$ & 103 & 35.4 \\
& $31-35$ & 83 & 28.5 \\
& $36-40$ & 38 & 13.1 \\
Education & $>40$ & 29 & 10 \\
& High school & 32 & 11 \\
& Bachelor & 241 & 82.8 \\
& Master or PhD & 18 & 6.2 \\
\hline \multirow{3}{*}{ Income (Yuan) } & $<2000$ & 11 & 3.8 \\
& $2000-5000$ & 67 & 23.0 \\
& $5000-8000$ & 131 & 45.0 \\
& $8000-15,000$ & 64 & 22.0 \\
& $>15,000$ & 18 & 6.2 \\
\hline
\end{tabular}

\section{Data Analysis and Results}

We analyzed the data using SmartPLS3.00. It has no strict assumption of normal data, nor does it require a large sample condition. Furthermore, it can run simultaneously measurement models and structural models while integrating confirmatory factor analysis and linear regression.

\subsection{Reliability and Validity}

To validate the measurement model, we assessed the reliability, convergent validity, and discriminant validity of all constructs assessed for the samples. To measure scale reliability, we computed composite reliability (CR) values [106]. The recommended threshold is 0.70 for both [107]. Table 2 shows that all CR values exceed 0.70 and fall between 0.806 and 0.870 , indicating the internal consistency of measured items and acceptable reliability [108].

The convergent validity method in the work of Fornell and Larcker [109] suggests that the convergent validity of variables is high if the average variance extracted (AVE) of all constructs exceeds 0.5 and all item loadings are significant and exceed 0.7. As Table 2 shows, the value of factor loadings exceeds 0.72 , and AVEs of all constructs fall between 0.559 and 0.769 . The results indicate adequate convergent validity. 
We evaluated discriminant validity using two criteria proposed by Fornell and Larcker [109]: correlations among constructs should be below 0.85 [110], and square roots of AVEs for each construct, should exceed correlations among other constructs in the model [109]. As Table 3 shows, the results met both criteria, demonstrating acceptable discriminant validity.

Table 2. Results of confirmatory factor analysis.

\begin{tabular}{|c|c|c|c|c|c|c|}
\hline Constructs & CR & AVE & Items & Mean & SD & Loading \\
\hline \multirow{2}{*}{ Consumer Loyalty } & \multirow{2}{*}{0.844} & \multirow{2}{*}{0.730} & CL1 & 0.744 & 0.744 & 0.879 \\
\hline & & & CL2 & 0.655 & 0.655 & 0.830 \\
\hline \multirow{2}{*}{ Idea Shopping } & \multirow{2}{*}{0.870} & \multirow{2}{*}{0.770} & IS1 & 0.771 & 0.771 & 0.873 \\
\hline & & & IS2 & 0.866 & 0.866 & 0.882 \\
\hline \multirow{3}{*}{ Cognitive Capital } & \multirow{2}{*}{0.824} & \multirow{2}{*}{0.701} & CC1 & 0.766 & 0.766 & 0.860 \\
\hline & & & $\mathrm{CC} 2$ & 0.679 & 0.679 & 0.814 \\
\hline & \multirow{5}{*}{0.835} & \multirow{4}{*}{0.559} & SC1 & 0.684 & 0.684 & 0.743 \\
\hline \multirow{4}{*}{ Structural Capital } & & & SC2 & 0.793 & 0.793 & 0.723 \\
\hline & & & SC3 & 0.754 & 0.754 & 0.766 \\
\hline & & & SC4 & 0.736 & 0.736 & 0.758 \\
\hline & & \multirow{3}{*}{0.559} & $\mathrm{RC} 1$ & 0.839 & 0.839 & 0.737 \\
\hline \multirow[t]{3}{*}{ Relational Capital } & \multirow[t]{3}{*}{0.835} & & $\mathrm{RC} 2$ & 0.766 & 0.766 & 0.824 \\
\hline & & & RC3 & 0.816 & 0.816 & 0.853 \\
\hline & & \multirow{3}{*}{0.581} & UV1 & 0.638 & 0.638 & 0.809 \\
\hline \multirow[t]{2}{*}{ Utilitarian Value } & \multirow[t]{2}{*}{0.806} & & UV2 & 0.726 & 0.726 & 0.716 \\
\hline & & & UV3 & 0.714 & 0.714 & 0.758 \\
\hline
\end{tabular}

Table 3. Correlations of latent variables.

\begin{tabular}{|c|c|c|c|c|c|c|c|c|c|c|}
\hline & 1 & 2 & 3 & 4 & 5 & 6 & 7 & 8 & 9 & 10 \\
\hline 1 Age & 1 & & & & & & & & & \\
\hline 2 Education & -0.029 & 1 & & & & & & & & \\
\hline 3 Gender & 0.116 & -0.041 & 1 & & & & & & & \\
\hline 4 Income & 0.260 & 0.277 & -0.003 & 1 & & & & & & \\
\hline 5 Structural Capital & 0.001 & 0.11 & -0.008 & 0.126 & 0.748 & & & & & \\
\hline 6 Relational Capital & -0.086 & 0.116 & -0.046 & 0.117 & 0.610 & 0.806 & & & & \\
\hline 7 Cognitive Capital & -0.005 & 0.135 & -0.006 & 0.184 & 0.636 & 0.435 & 0.837 & & & \\
\hline 8 Utilitarian Value & 0.024 & 0.019 & -0.078 & 0.048 & 0.511 & 0.380 & 0.583 & 0.762 & & \\
\hline 9 Idea Shopping & -0.053 & 0.086 & -0.058 & 0.107 & 0.544 & 0.417 & 0.388 & 0.370 & 0.877 & \\
\hline 10 Consumer Loyalty & 0.013 & 0.04 & -0.075 & 0.085 & 0.558 & 0.485 & 0.545 & 0.576 & 0.492 & 0.855 \\
\hline
\end{tabular}

Note: Square roots of AVE appear in bold font.

To assess multicollinearity, we calculated variance inflation factor values for all constructs in the model. None exceeded 1.6, indicating no serious multicollinearity. We tested for common method bias (CMB) because all samples were self-reported and collected simultaneously. Following the study of Podsakoff and Organ [111], we used Harmon's one-factor test to assess CMB. The results revealed that the first factor accounts for $39.8 \%$ of variance in the model, but no single factor accounts for a majority of the variance.

\subsection{Structural Model Analysis}

We estimated the theoretical model and hypotheses via bootstrapping to determine path significance and explanatory power (bootstrapped sample $=1000$ ). Figure 2 shows the results of partial least squares (PLS) analysis. First, we examined the relationships among the three dimensions of social capital and perceived value. The results indicated that structural capital exerts significant positive effects on utilitarian value $(\beta=0.191, p<0.001)$ and idea shopping $(\beta=0.426, p<0.001)$. Hypotheses 1 and 2 are supported. 
Relational capital exhibits significant positive effects on idea shopping $(\beta=0.131, p<0.05)$, but not on utilitarian value ( $\beta=0.070, p>0.05$ ). Hypothesis 3 is not supported, and Hypothesis 4 is.

Cognitive capital has positive and significant effects on utilitarian value $(\beta=0.430, p<0.001)$, but not on idea shopping $(\beta=0.060, p>0.05)$. Hypothesis 5 is supported, and Hypothesis 6 is not.

Second, we examined how each type of value affected loyalty to the IOO platform. The path from utilitarian value $(\beta=0.456, p<0.001)$ to loyalty to the platform is positive and significant, supporting Hypothesis 7.

Hypothesis 8 concerning the relationship between idea shopping and loyalty to the platform $(\beta=0.318, p<0.001)$ is supported.

With respect to indirect effects of perceived value, we found that utilitarian value mediated the impact of structural and cognitive capital on loyalty $(\beta=0.196, p<0.001 ; \beta=0.087, p<0.05$, respectively). Idea shopping also mediates the impact of structural and relational capital on loyalty $(\beta=0.135, p<0.001 ; \beta=0.042, p<0.05$, respectively) (Table 4$) . R^{2}$ measures the explanatory power of independent variables. It shows that $42.3 \%$ of variance in consumer loyalty is explained by the three dimensions of social capital and two aspects of perceived value. Furthermore, $R^{2}$ for utilitarian value (0.377) and idea shopping value (0.311) showed that the antecedents of social capital explain a significant proportion of variation in these variables.

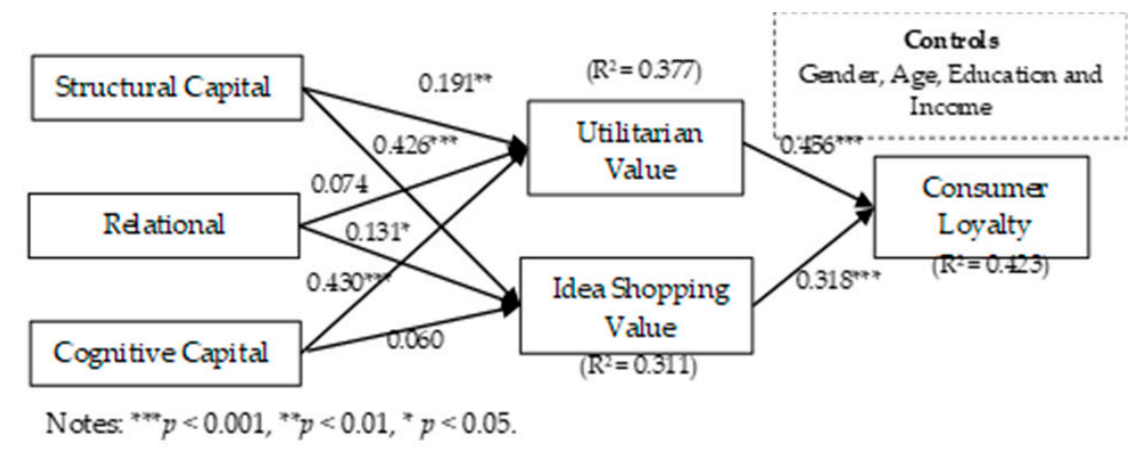

Figure 2. Results of structural model analysis.

Table 4. Results of indirect effects

\begin{tabular}{ccc}
\hline Indirect Effect & $\begin{array}{c}\text { Indirect } \\
\text { Effect Coefficients }\end{array}$ & $\begin{array}{c}\text { 95\% Bias Corrected } \\
\text { Confidence Intervals }\end{array}$ \\
\hline Cognitive Capital $\rightarrow$ Idea Shopping $\rightarrow$ Loyalty & 0.019 & {$[-0.026,0.073]$} \\
Structural Capital $\rightarrow$ Idea Shopping $\rightarrow$ Loyalty & 0.135 & {$[0.075,0.212]$} \\
Relative Capital $\rightarrow$ Idea Shopping $\rightarrow$ Loyalty & 0.042 & {$[0.004,0.093]$} \\
Cognitive Capital $\rightarrow$ Utilitarian Value $\rightarrow$ Loyalty & 0.196 & {$[0.116,0.282]$} \\
Structural Capital $\rightarrow$ Utilitarian Value $\rightarrow$ Loyalty & 0.087 & {$[0.014,0.162]$} \\
Relative Capital $\rightarrow$ Utilitarian Value $\rightarrow$ Loyalty & 0.034 & {$[-0.017,0.092]$} \\
\hline
\end{tabular}

\section{Discussion and Implications}

\subsection{Discussion}

The growing significance of marketing IOO platforms motivates researchers to explore factors that influence loyalty to IOO platforms. The characteristics of IOO consumers motivate researchers to explore how perceived value and other factors influence loyalty to IOO platforms. This study verified that perceived utilitarian value and idea shopping value influence loyalty to IOO platforms and mediate how social capital affects loyalty.

First, in the context of IOO, social capital presents a useful perspective for improving consumers' perceived value. Consistent studies of other e-commerce scenarios that use social capital theory $[4,21,86]$, we clarified the relationships among dimensions of social capital and perceived values in IOO platforms. 
However, the three types of perceived social capital have differing relations with perceived value. On the one hand, the results show that structural capital and cognitive capital increase utilitarian value, whereas relational capital exerts no impact on it. Further, our results show that cognitive capital exerts a stronger effect on utilitarian value. An explanation may be that time and money are an important aspect of shopping online. Social interaction ties provide opportunities of communication, and shared language enhances the efficiency of communication [4]. Utilitarian value involves consumers perceived convenience and monetary saving, and so on. Through communicating among consumers, consumers could access and understand more useful information to help making decision.

On the other hand, structural and relational capital have a significant impact on perceived idea shopping value, and structural capital exerts a stronger effect on idea shopping value. That is because frequent social interactions, a manifestation of structural capital, help consumers know each other and show "fashion".

Similarly, relationship capital reflects interpersonal relationships. Better relationships are conducive to the consumer's pursuit of "new" products and "new" methods in the riskier context of IOO shopping [86], and to establish and keep the identity of leaders in fashion consumption. Contrary to our expectations, shared language exerts no significant impact on perceived idea shopping value. Perhaps consumers who share language with other IOO shoppers focus more on the efficiency of online outshopping than the experience of it. This implies that they may contribute simply for the time saving or economical aspect, and not for the purpose of "fashion".

Second, we found that both utilitarian and idea shopping values affirmatively affect consumer loyalty to IOO platforms. Among IOO consumers, utilitarian value is important for domestic online shoppers [16] and offline cross-border shoppers. In addition, the value of fashion consumption influences repeat visits to IOO platforms. We find that if consumers repeatedly shop on an IOO platform, the satisfaction of acquiring "fashion" explains their loyalty. This finding demonstrates that IOO platforms aid consumers' pursuit of "fashion" or "novelty" and somewhat satisfy their desire for "novelty".

Third, our results show that perceived value mediates the impact of social capital on consumer loyalty to an IOO platform. Moreover, values have different mediating effects on the relation between components of social capital and loyalty. For example, utilitarian value mediates how structural and cognitive capital affects consumer loyalty, whereas idea shopping value mediates how structural and relational capital affect it. As mentioned above, both utilitarian value and hedonic value are positively associated with consumers' loyalty. On the one hand, social interactive ties and shared language increase the opportunity and efficiency of communication, respectively, in turn promoting shopping efficiency. Shopping efficiency is mainly manifested by convenience, product offerings, product information and monetary savings. Thus, utilitarian value mediated the influence of structural capital and cognitive capital on consumers' loyalty. On the other hand, social interactions and trust promote showing and keeping of "fashion" identity among consumers, respectively. The "fashion" identity explains consumers' attempt to make sense of themselves. For consumers, structural and relational capital influence their loyalty through perceived idea shopping value. These findings show that outshoppers pursue different values and that such values play different roles.

\subsection{Theory Implications}

This study offers several implications for theory. First, it provides granular insights into the nature of social capital and its impact on consumer value in IOO scenarios. Previous studies widely used social capital to test interactions between people, such as information exchange and knowledge sharing [21,112]. Few studies have examined how social capital relates to IOO platforms. This study takes the initiative in adopting social capital as antecedent to consumers' perceptions of value and demonstrating the relationships between them.

Second, our conclusions enrich the understanding of how the three dimensions of social capital affect consumers' perceived values. Specifically, structural and cognitive capitals exert significant 
positive effects on functional value, whereas fashion consumption value is influenced by structural and relational capital but not cognitive capital. This finding verifies that the three dimensions of social capital have different mechanisms of action in different research contexts. In the context of C2C, Huang et al. [4] found that their roles differ for different satisfactions. They also have different effects on quantity and quality of knowledge-sharing [86]. In the context of firm-based communities, dimensions of social capital have different effects on users' continued use [113].

Third, we find that different values still have significant positive effects on consumer loyalty. As many studies have confirmed, utilitarian and hedonic value have significant positive effects on consumer loyalty $[6,80,114]$. Drawing from earlier research, we find that idea shopping (a hedonic value) is important in IOO contexts. This finding deepens our understanding of consumers' pursuit of different values in choosing IOO platforms while expanding application of value theory.

Fourth, our research expands upon the direct effects of social capital found in earlier research into consumers' continued behavior. It describes how different dimensions of social capital affect consumer loyalty as mediated by utilitarian value and fashion consumption value (Table 4 ). This suggests that social capital does not fully influence loyalty to IOO platforms, but more likely promotes loyalty through utilitarian value and fashion consumption value.

\subsection{Practical Implications}

This study has several practical applications. First, generating social capital among consumers fosters their loyalty to IOO platforms. Methods for generating social capital include providing technical support, such as instant messaging, online forums, and Q\&A functions to promote consumer interactions. Many IOO platforms limit communication between consumers to posting and reading comments. Designers of IOO platforms should encourage instant communication and Q\&A as interactive functions.

Second, the managers of IOO platforms and sellers should encourage consumer communication and exchange. Strategies include incentives and events that generate consumers' social capital.

Third, platform managers should help consumers develop social capital that dovetails with different values. Consumers who emphasize utility should be provided with more opportunities to strengthen structural and cognitive capital. For consumers concerned about fashion, platforms should establish communication channels and trust mechanisms to facilitate relationship capital.

\section{Limitation and Future Research}

Our study's limitations suggest that future research is warranted. First, we used cross-sectional data to test the model. Since IOO platforms are dynamic, the relationship between social capital and perceived value may be a persistent phenomenon. Therefore, a time-based vertical design could validate models and explore changing capital in social interactions within IOO platforms.

Second, we mainly addressed social capital among consumers. In e-commerce, social capital pertains to consumers, sellers, and platforms, and it affects the consumers' perception of value and loyalty. Therefore, future research should consider social capital among different objects.

Third, in view of the characteristics of IOO consumers, we considered only shopping for fashion (idea shopping) as a hedonic value. More value factors deserve consideration. Fourth, we surveyed Chinese consumers. Comparative research in other countries and cultures will generate more universal results.

\section{Conclusions}

This study has upheld our conjectures about the relationships between consumer social capital, consumer-perceived shopping value, and loyalty to IOO platforms. This research, grounded in social capital theory, consumption value theory, and characteristics of IOO consumers, proposes that the three dimensions of consumer social capital (structural, relational, and cognitive) boost the utilitarian value of consumers and the perception of fashion consumption value. These, in turn, foster consumer loyalty. 
The dimensions of social capital have differing effects on diverse consumption values. Structured capital can promote functional and fashion consumption value at the same time, whereas cognitive capital promotes only utilitarian value among consumers. Relational capital effectively promotes only value that consumers assign to shopping for fashion. We found that structural capital acts on consumer loyalty through utilitarian value and fashion value, whereas cognitive capital acts on consumer loyalty only through utilitarian value, and relational capital acts on consumer loyalty only through fashion consumption value. In sum, this study provides theoretical and practical guidance to improve consumer loyalty to IOO platforms. Future research should explore different components of social capital and different consumption values in IOO environments.

Author Contributions: Y.L. and Q.Y. have been involved in all the steps of the study: literature review, theoretical design, data collection, statistical analysis and the writing of the paper.

Funding: This research was funded by the National Natural Science Foundation of China under Grant (71402159,71162005,71362016), Yunnan Province Young Academic and Technical Leader candidate Program (2018HB027), Yunnan Science and Technology Fund (2017FA034), Yunnan Provincial E-Business Entrepreneur Innovation Interactive Space (2017DS012) \& Kunming Key Laboratory of E-Business and Internet Finance (2017-1A-14684,KGF[2018]18), Educational and Teaching Reform Fund of Yunnan University (2019) and Yunnan Provincial E-Business Innovation and Entrepreneurship Key Laboratory of colleges and universities (YES 2014 [16]), and the Prominent Educator Program (Yunnan[2018]11).

Conflicts of Interest: The authors declare no conflicts of interest.

\section{Appendix A}

Table A1 shows items that represent and measure the study's six latent variables.

Table A1. Constructs and their measurement items.

\begin{tabular}{|c|c|c|}
\hline Constructs & Measurement Items & References \\
\hline Social ties (ST) & $\begin{array}{l}\text { ST1 Shopping on this IOO website allows me to communicate and } \\
\text { exchange with other members. } \\
\text { ST2 While shopping on this IOO website, I like to communicate and } \\
\text { exchange with other members. } \\
\text { ST3 While shopping on this IOO website, everyone will help and share } \\
\text { with each other. } \\
\text { ST4 For me, shopping on this IOO website constitutes an opportunity to } \\
\text { communicate and exchange with other members. }\end{array}$ & \multirow[t]{3}{*}{$\begin{array}{l}\text { Chiu, Hsu and } \\
\text { Wang [85] }\end{array}$} \\
\hline Trust (TR) & $\begin{array}{l}\text { TR1 Members of this IOO website do not take advantage of each other. } \\
\text { TR2 Members of this IOO website have mutual trust. } \\
\text { TR3 Members of this IOO website sincerely treat each other. }\end{array}$ & \\
\hline $\begin{array}{l}\text { Shared } \\
\text { language (SL) }\end{array}$ & $\begin{array}{l}\text { SL1 On this IOO website, we use certain understandable ways } \\
\text { to communicate. } \\
\text { SL2 On this IOO website, we use understandable descriptions in } \\
\text { released information and content. }\end{array}$ & \\
\hline $\begin{array}{l}\text { Utilitarian } \\
\text { value (UV) }\end{array}$ & $\begin{array}{l}\text { UV1 This IOO website provides a number of product offerings and suits } \\
\text { the buyers' preferences. } \\
\text { UV2 I saved money when I shopped on this IOO website. } \\
\text { UV3 Using this IOO website would be a convenient way to shop. }\end{array}$ & \multirow[t]{2}{*}{$\begin{array}{l}\text { Chiu, Wang, } \\
\text { Fang and } \\
\text { Huang [6] }\end{array}$} \\
\hline $\begin{array}{l}\text { Idea } \\
\text { shopping (IS) }\end{array}$ & $\begin{array}{l}\text { IS1 I shop on this IOO website to keep up with trends. } \\
\text { IS2 I shop on this IOO website to keep up with new fashions. }\end{array}$ & \\
\hline $\begin{array}{l}\text { Consumer } \\
\text { loyalty }(C L)\end{array}$ & $\begin{array}{l}\text { CL1 I will recommend this IOO website to others. } \\
\text { CL2 I will continue using this IOO website. }\end{array}$ & Gefen [77] \\
\hline
\end{tabular}




\section{References}

1. Ramkumar, B.; Jin, B. Exploring Factors that Influence US Consumers' International Online Outshopping (IOO) Intentions at E-Tailers in Developing Countries: Propositions; Springer International Publishing: New York City, NY, USA, 2016.

2. Boeuf, B.; Sénécal, S. Online international outshopping experience: Proposition of a research model. Rech. Appl. Mark 2013, 28, 110-119. [CrossRef]

3. Anderson, R.E.; Srinivasan, S.S. E-satisfaction and e-loyalty: A contingency framework. Psychol. Mark. 2003, 20, 123-138. [CrossRef]

4. Huang, Q.; Chen, X.; Ou, C.X.; Davison, R.M.; Hua, Z. Understanding buyers' loyalty to a C2C platform: The roles of social capital, satisfaction and perceived effectiveness of e-commerce institutional mechanisms. Inf. Syst. J. 2015, 27, 91-119. [CrossRef]

5. Campbell, D.E.; Wells, J.D.; Valacich, J.S. Breaking the Ice in B2C Relationships: Understanding Pre-Adoption E-Commerce Attraction. Inf. Syst. Res. 2013, 24, 219-238. [CrossRef]

6. Chiu, C.M.; Wang, E.T.G.; Fang, Y.H.; Huang, H.Y. Understanding customers' repeat purchase intentions in B2C e-commerce: The roles of utilitarian value, hedonic value and perceived risk. Inf. Syst. J. 2014, 24, 85-114. [CrossRef]

7. Baruca, A.; Zolfagharian, M.A. Cross-Border Shopping: Mexican Shoppers in the US and American Shoppers in Mexico. Int. J. Consum. Stud. 2013, 37, 360-366. [CrossRef]

8. Dmitrovic, T.; Vida, I. An examination of cross-border shopping behaviour in South-East Europe. Eur. J. Mark. 2007, 41, 382-395. [CrossRef]

9. Guo, C.; Wang, Y.J. A study of cross-border outshopping determinants: Mediating effect of outshopping enjoyment. Int. J. Consum. Stud. 2010, 33, 644-651. [CrossRef]

10. Wang, Y.; Doss, S.K.; Guo, C.; Li, W. An investigation of Chinese consumers' outshopping motives from a culture perspective: Implications for retail and distribution. Int. J. Retail Distrib. Manag. 2010, 38, 423-442. [CrossRef]

11. Safari, A.; Thilenius, P. Alleviating uncertainty through trust: A narrative approach to consumers' foreign online purchasing behaviour. J. Cust. Behav. 2013, 12, 211-226. [CrossRef]

12. Wagner, G.; Schramm-Klein, H.; Schu, M. Determinants and Moderators of Consumers' Cross-Border Online Shopping Intentions. Mark. ZFP 2016, 38, 214-227. [CrossRef]

13. Jones, M.A.; Reynolds, K.E.; Arnold, M.J. Hedonic and utilitarian shopping value: Investigating differential effects on retail outcomes. J. Bus. Res. 2006, 59, 974-981. [CrossRef]

14. Gutman, J. Means-end chains as goal hierarchies. Psychol. Mark. 1997, 14, 545-560. [CrossRef]

15. El-Adly, M.I. Modelling the relationship between hotel perceived value, customer satisfaction, and customer loyalty. J. Retail. Consum. Serv. 2018, 50, 322-332. [CrossRef]

16. Yoo, J.; Park, M. The effects of e-mass customization on consumer perceived value, satisfaction, and loyalty toward luxury brands. J. Bus. Res. 2016, 69, 5775-5784. [CrossRef]

17. Boeuf, B.; Sénécal, S. Online International Outshopping Experience: Proposition of a Research Model; Springer International Publishing: New York City, NY, USA, 2016; pp. 110-119.

18. iiMedia 2016-2017 China Importing E-business Market. Available online: http://www.iimedia.cn/47588.html (accessed on 27 September 2019).

19. Zahedi, F.; Lu, Y. Website Personalization for Relationship Building: A Conceptual Framework. In Proceedings of the Ninth Americas Conference Information Systems, Tampa, FL, USA, 4-6 August 2003; pp. $2256-2264$.

20. Adler, P.S.; Kwon, S.-W. Social capital: Prospects for a new concept. Acad. Manag. Rev. 2002, $27,17-40$. [CrossRef]

21. Wang, J.; Chiang, M.J. Social interaction and continuance intention in online auctions: A social capital perspective. Decis. Support Syst. 2009, 47, 466-476. [CrossRef]

22. Parasuraman, A. Reflections on gaining competitive advantage through customer value. J. Acad. Mark. Sci. 1997, 25, 154-161. [CrossRef]

23. Zeithaml, V.A. Consumer perceptions of price, quality, and value: A means-end model and synthesis of evidence. J. Mark. 1988, 52, 2-22. [CrossRef]

24. Walter, A.; Ritter, T.; Gemünden, H.G. Value Creation in Buyer-Seller Relationships: Theoretical Considerations and Empirical Results from a Supplier's Perspective. Ind. Mark. Manag. 2001, 30, 365-377. [CrossRef] 
25. Liljander, V.; Strandvik, T. Estimating Zones of Tolerance in Perceived Service Quality and Perceived Service Value. Int. J. Serv. Ind. Manag. 1993, 4, 6-28. [CrossRef]

26. Afuah, A. Mapping technological capabilities into product markets and competitive advantage: The case of cholesterol drugs. Strateg. Manag. J. 2002, 23, 171-179. [CrossRef]

27. Batra, R.; Ahtola, O.T. Measuring the Hedonic and Utilitarian Sources of Consumer Attitudes. Mark. Lett. 1991, 2, 159-170. [CrossRef]

28. Dhar, R.; Wertenbroch, K. Consumer Choice between Hedonic and Utilitarian Goods. J. Mark. Res. 2000, 37, 60-71. [CrossRef]

29. Kakar, A.K.S. Why do users prefer the hedonic but choose the Utilitarian? Investigating user dilemma of hedonic-utilitarian choice. Int. J. Hum. Comput. Stud. 2017, 108, 50-61. [CrossRef]

30. Hong, J.C.; Lin, P.H.; Hsieh, P.C. The effect of consumer innovativeness on perceived value and continuance intention to use smartwatch. Comput. Hum. Behav. 2017, 67, 264-272. [CrossRef]

31. Hirschman, E.C.; Holbrook, M.B. Hedonic Consumption: Emerging Concepts, Methods and Propositions. J. Mark. 1982, 46, 92-101. [CrossRef]

32. Arnold, M.J.; Reynolds, K.E. Hedonic shopping motivations. J. Retail. 2003, 79, 77-95. [CrossRef]

33. Diefenbach, S.; Kolb, N.; Hassenzahl, M. The 'hedonic' in human-computer interaction: History, contributions, and future research directions. In Proceedings of the 2014 Conference on Designing Interactive Systems, Vancouver, BC, Canada, 21-25 June 2014; ACM: Vancouver, BC, Canada, 2014; pp. 305-314.

34. Davis, F.D. Perceived Usefulness, Perceived Ease of Use, and User Acceptance of Information Technology. MIS Q. 1989, 13, 319-340. [CrossRef]

35. Venkatesh, V. Creation of Favorable User Perceptions: Exploring the Role of Intrinsic Motivation. MIS Q. 1999, 23, 239-260. [CrossRef]

36. Van der Heijden, H. User Acceptance of Hedonic Information Systems. MIS Q. 2004, 28, 695-704. [CrossRef]

37. Deci, E.; Ryan, R.M. Intrinsic Motivation and Self-Determination in Human Behavior; Plenum Press: New York, NY, USA, 1985; pp. 437-448.

38. Shang, R.A.; Chen, Y.C.; Shen, L. Extrinsic versus intrinsic motivations for consumers to shop on-line. Inf. Manag. 2005, 42, 401-413. [CrossRef]

39. Babin, B.J.; Darden, W.R.; Griffin, M. Work and/or Fun: Measuring Hedonic and Utilitarian Shopping Value. J. Consum. Res. 1994, 20, 644-656. [CrossRef]

40. Childers, T.L.; Carr, C.L.; Peck, J.; Carson, S. Hedonic and utilitarian motivations for online retail shopping behavior. J. Retail. 2001, 77, 511-535. [CrossRef]

41. Bridges, E.; Florsheim, R. Hedonic and utilitarian shopping goals: The online experience. J. Bus. Res. 2008, 61, 309-314. [CrossRef]

42. Kesari, B.; Atulkar, S. Satisfaction of mall shoppers: A study on perceived utilitarian and hedonic shopping values. J. Retail. Consum. Serv. 2016, 31, 22-31. [CrossRef]

43. Overby, J.W.; Lee, E.J. The effects of utilitarian and hedonic online shopping value on consumer preference and intentions. J. Bus. Res. 2006, 59, 1160-1166. [CrossRef]

44. Pe-Than, E.P.P.; Goh, D.H.-L.; Lee, C.S. Why do people play human computation games? Effects of perceived enjoyment and perceived output quality. Aslib J. Inf. Manag. 2015, 67, 592-612. [CrossRef]

45. Ballantine, P.W. Effects of interactivity and product information on consumer satisfaction in an online retail setting. Int. J. Retail Distrib. Manag. 2005, 33, 461-471. [CrossRef]

46. Nahapiet, J.; Ghoshal, S. Social Capital, Intellectual Capital, and the Organizational Advantage. Knowl. Soc. Cap. 1998, 23, 242-266.

47. Coleman, J.S. Social capital in the creation of human capital. Am. J. Sociol. 1988, 94, S95-S120. [CrossRef]

48. Luo, J.; Zhao, Y.; Li, P. Social Capital Levels and Measurements: Theory and Practice; Social Science Academic Publisher: Beijing, China, 2005.

49. Putnam, R.D. Making Democracy Work: Civic Traditions in Modern Italy; Princeton Univeristy Press: Princeton, NJ, USA, 1993.

50. Hsu, M.H.; Chang, C.M. Examining interpersonal trust as a facilitator and uncertainty as an inhibitor of intra-organisational knowledge sharing. Inf. Syst. J. 2014, 24, 119-142. [CrossRef]

51. Sun, Y.; Fang, Y.; Lim, K.H.; Straub, D. User Satisfaction with Information Technology Services: A Social Capital Perspective. Inf. Syst. Res. 2012, 23, 1195-1211. [CrossRef] 
52. Tsai, W.; Ghoshal, S. Social capital and value creation: The role of intrafirm networks. Acad. Manag. J. 1998, 41, 464-476.

53. Putnam, R.D. Tuning in, tuning out: The strange disappearance of social capital in America. Polit. Sci. Polit. 1995, 28, 664. [CrossRef]

54. Yli-Renko, H.; Autio, E.; Sapienza, H.J. Social Capital, Knowledge Acquisition, and Knowledge Exploitation in Young Technology-Based Firms. Strateg. Manag. J. 2001, 22, 587-613. [CrossRef]

55. Wasko McLure, M.; Faraj, S. Why should I share? Examining social capital and knowledge contribution in electronic networks of practice. MIS Q. 2005, 29, 35-57. [CrossRef]

56. Chang, H.H.; Chuang, S.S. Social capital and individual motivations on knowledge sharing: Participant involvement as a moderator. Inf. Manag. 2011, 48, 9-18. [CrossRef]

57. Chen, A.; Lu, Y. Users' Active Behavior in SNSs: Integrating Commitment, Social Support, Sunk Cost and Social Influence Perspective. Nankai Bus. Rev. 2014, 17, 30-39.

58. Lee, M.R.; Yen, D.C.; Hsiao, C.Y. Understanding the perceived community value of Facebook users. Comput. Hum. Behav. 2014, 35, 350-358. [CrossRef]

59. Piyathasanan, B.; Mathies, C.; Wetzels, M.; Patterson, P.G.; Ruyter, K.D. A Hierarchical Model of Virtual Experience and Its Influences on the Perceived Value and Loyalty of Customers. Int. J. Electron. Commer. 2015, 19, 126-158.

60. Zhang, C.B.; Li, Y.N.; Wu, B.; Li, D.J. How WeChat can retain users: Roles of network externalities, social interaction ties, and perceived values in building continuance intention. Comput. Hum. Behav. 2016, 69, S0747563216308184. [CrossRef]

61. Lin, K.Y.; Lu, H.P. Why people use social networking sites: An empirical study integrating network externalities and motivation theory. Comput. Hum. Behav. 2011, 27, 1152-1161. [CrossRef]

62. Wang, E.S.; Chen, L.S. Forming relationship commitments to online communities: The role of social motivations. Comput. Hum. Behav. 2012, 28, 570-575. [CrossRef]

63. Hossain, M.A.; Jahan, N.; Fang, Y.; Hoque, S. Nexus of Electronic Word-Of-Mouth to Social Networking Sites: A Sustainable Chatter of New Digital Social Media. Sustainability 2019, 11, 759. [CrossRef]

64. Zahedi, F.M.; Bansal, G.; Ische, J. Success Factors in Cooperative Online Marketplaces: Trust as the Social Capital and Value Generator in Vendors-Exchange Relationships. J. Organ. Comput. Electron. Commer. 2010, 20, 295-327. [CrossRef]

65. Chou, S.W.; Hsu, C.S. Understanding online repurchase intention: Social exchange theory and shopping habit. Inf. Syst. e-Bus. Manag. 2016, 14, 19-45. [CrossRef]

66. Kim, D.J.; Ferrin, D.L.; Rao, H.R. Trust and satisfaction, two stepping stones for successful e-commerce relationships: A longitudinal exploration. Inf. Syst. Res. 2009, 20, 237-257. [CrossRef]

67. Zhang, T.; Agarwal, R.; Lucas, H.C., Jr. The Value of IT-Enabled Retailer Learning: Personalized Product Recommendations and Customer Store Loyalty in Electronic Markets. MIS Q. 2011, 35, 859-881.

68. Yang, S.; Zhou, X. Virtual Social Capital, eWOM and Purchasing Behavior. Res. Econ. Manag. 2011, 6, $109-115$.

69. Jiang, Y.; Shang, J.; Liu, Y. Maximizing customer satisfaction through an online recommendation system: A novel associative classification model. Decis. Support Syst. 2010, 48, 470-479. [CrossRef]

70. Shen, K.N.; Khalifa, M. System design effects on online impulse buying. Internet Res. 2012, 22, $396-425$. [CrossRef]

71. Animesh, A.; Pinsonneault, A.; Yang, S.B.; Oh, W. An Odyssey into Virtual Worlds: Exploring the Impacts of Technological and Spatial Environments. MIS Q. 2011, 35, 789-810. [CrossRef]

72. Hsu, C.-L.; Chang, K.-C.; Kuo, N.-T.; Cheng, Y.-S. The mediating effect of flow experience on social shopping behavior. Inf. Dev. 2017, 33, 243-256. [CrossRef]

73. Oliver, R. Satisfaction: A Behavioral Perspective of the Consumer; McGraw-Hill: New York, NY, USA, 1997.

74. Dick, A.S.; Basu, K. Customer loyalty: Toward an integrated conceptual framework. J. Acad. Mark. Sci. 1994, 22, 99-113. [CrossRef]

75. Jacoby, J.; Chestnut, R. Brand Loyalty Measurement and Management. J. Mark. Res. 1973, 15, 1-9. [CrossRef]

76. Gruen, T.W.; Osmonbekov, T.; Czaplewski, A.J. eWOM: The impact of customer-to-customer online know-how exchange on customer value and loyalty. J. Bus. Res. 2006, 59, 449-456. [CrossRef]

77. Corstjens, M.; Lal, R. Building Store Loyalty through Store Brands. J. Mark. Res. 2000, 37, 281-291. [CrossRef]

78. Gefen, D. Customer Loyalty in e-Commerce. J. Assoc. Inf. Syst. 2002, 3, 27-51. [CrossRef] 
79. Srinivasan, S.S.; Anderson, R.; Ponnavolu, K. Customer loyalty in e-commerce: An exploration of its antecedents and consequences. J. Retail. 2002, 78, 41-50. [CrossRef]

80. Toufaily, E.; Ricard, L.; Perrien, J. Customer loyalty to a commercial website: Descriptive meta-analysis of the empirical literature and proposal of an integrative model. J. Bus. Res. 2013, 66, 1436-1447. [CrossRef]

81. Reyes-Menendez, A.; Palos-Sanchez, P.R.; Ramon Saura, J.; Martin-Velicia, F. Understanding the Influence of Wireless Communications and Wi-Fi Access on Customer Loyalty: A Behavioral Model System. Wirel. Commun. Mob. Comput. 2018, 2018, 3487398. [CrossRef]

82. Zheng, X.; Cheung, C.M.K.; Lee, M.K.O.; Liang, L. Building brand loyalty through user engagement in online brand communities in social networking sites. Inf. Technol. People 2016, 28, 90-106. [CrossRef]

83. Harris, L.C.; Goode, M.M.H. The four levels of loyalty and the pivotal role of trust: A study of online service dynamics. J. Retail. 2004, 80, 139-158. [CrossRef]

84. Cronin, J.J.; Brady, M.K.; Hult, G.T.M. Assessing the effects of quality, value, and customer satisfaction on consumer behavioral intentions in service environments. J. Retail. 2000, 76, 193-218. [CrossRef]

85. Chaston, I.; Mangles, T. Relationship marketing in online business-to-business markets. Eur. J. Mark. 2003, 37, 753-773. [CrossRef]

86. Chiu, C.M.; Hsu, M.H.; Wang, E.T.G. Understanding knowledge sharing in virtual communities: An integration of social capital and social cognitive theories. Decis. Support Syst. 2006, 42, 1872-1888. [CrossRef]

87. Cohen, D.J.; Prusak, L. Good Company: How Social Capital Makes Organizations Work; Harvard Business School Press: Boston, MA, USA, 2001.

88. Fukuyama, F. Trust: The Social Virtues and the Creation of; The Free Press: New York, NY, USA, 1995.

89. Greenberg, P.S.; Greenberg, R.H.; Antonucci, Y.L. Creating and sustaining trust in virtual teams. Bus. Horiz. 2007, 50, 325-333. [CrossRef]

90. Schoorman, F.D.; Mayer, R.C.; Davis, J.H. An integrative model of organizational trust: Past, present, and future. Acad. Manag. Rev. 1995, 20, 709-734. [CrossRef]

91. Mathwick, C.; Wiertz, C.; Ruyter, K.D. Social Capital Production in a Virtual P3 Community. J. Consum. Res. 2008, 34, 832-849. [CrossRef]

92. Lesser, E.L.; Storck, J. Communities of practice and organizational performance. IBM Syst. J. 2001, 40, 831-841. [CrossRef]

93. Wood, W. Attitude Change: Persuasion and Social Influence. Annu. Rev. Psychol. 2000, 51, 539. [CrossRef] [PubMed]

94. Duncan, T.; Moriarty, S.E. A Communication-Based Marketing Model for Managing Relationships. J. Mark. 1998, 62, 1-13. [CrossRef]

95. Wolfinbarger, M.; Gilly, M.C. Shopping Online for Freedom, Control, and Fun. Calif. Manag. Rev. 2001, 43, 34-55. [CrossRef]

96. Oghuma, A.P.; Libaque-Saenz, C.F.; Wong, S.F.; Chang, Y. An expectation-confirmation model of continuance intention to use mobile instant messaging. Telemat. Inf. 2016, 33, 34-47. [CrossRef]

97. Fang, J.; Wen, C.; George, B.; Prybutok, V. Consumer Heterogeneity, Perceived Value, and Repurchase Decision-Making in Online Shopping: The Role of Gender, Age, and Shopping Motives. J. Electron. Commer. Res. 2016, 17, 116-131.

98. Jasperson, J.; Carter, P.E.; Zmud, R.W. A comprehensive conceptualization of post-adoptive behaviors associated with information technology enabled work systems. MIS Q. 2005, 29, 525-557. [CrossRef]

99. Kim, H.W.; Chan, H.C.; Chan, Y.P. A balanced thinking-feelings model of information systems continuance. Int. J. Hum. Comput. Stud. 2007, 65, 511-525. [CrossRef]

100. Hou, C.-K. Understanding business intelligence system continuance intention: An empirical study of Taiwan's electronics industry. Inf. Dev. 2016, 32, 1359-1371. [CrossRef]

101. Museli, A.; Jafari Navimipour, N. A model for examining the factors impacting the near field communication technology adoption in the organizations. Kybernetes 2018, 47, 1378-1400. [CrossRef]

102. Davis, F.D.; Bagozzi, R.P.; Warshaw, P.R. Extrinsic and Intrinsic Motivation to Use Computers in the Workplace. J. Appl. Soc. Psychol. 1992, 22, 1111-1132. [CrossRef]

103. Lin, C.S.; Wu, S.; Tsai, R.J. Integrating perceived playfulness into expectation-confirmation model for web portal context. Inf. Manag. 2005, 42, 683-693. [CrossRef] 
104. Atulkar, S.; Kesari, B. Satisfaction, loyalty and repatronage intentions: Role of hedonic shopping values. J. Retail. Consum. Serv. 2017, 39, 23-34. [CrossRef]

105. Chang, W.-L.; Chang, C.-J. Hedonic experience of customer re-patronizing intention: A system dynamics viewpoint. Kybernetes 2017, 46, 1674-1691. [CrossRef]

106. Werts, C.E.; Linn, R.L.; Jöreskog, K.G. Intraclass Reliability Estimates: Testing Structural Assumptions. Educ. Psychol. Meas. 1974, 34, 25-33. [CrossRef]

107. Nunnally, J.C.; Bernstein, I.H. Psychometric Theory. Am. Educ. Res. J. 1994, 56, 83-95.

108. Gefen, D.; Straub, D.W.; Boudreau, M.C. Structural equation modeling and regression: Guidelines for research practice. Commun. Assoc. Inf. Syst. 2000, 4, 7. [CrossRef]

109. Fornell, C.; Larcker, D.F. Evaluating structural equation models with unobservable variables and measurement error. J. Mark. Res. 1981, 18, 39-50. [CrossRef]

110. Kline, R.B.; Santor, D.A. Reviews of Using LISREL for Structural Equation Modelling: A Researcher's Guide and Principles and Practice of Structural Equation Modelling. Can. Psychol. 1999, 40, 381.

111. Podsakoff, P.M.; Organ, D.W. Self-reports in organizational research: Problems and prospects. J. Manag. 1986, 12, 531-544. [CrossRef]

112. Kankanhalli, A.; Tan, B.C.Y.; Kwok-Kee, W. Contributing knowledge to electronic knowledge repositories: An ecpirical investigation. MIS Q. 2005, 29, 113-143. [CrossRef]

113. Guo, W.; Liang, R.-Y.; Wang, L.; Peng, W. Exploring sustained participation in firm-hosted communities in China: The effects of social capital and active degree. Behav. Inf. Technol. 2017, 36, 223-242. [CrossRef]

114. Ozturk, A.B.; Nusair, K.; Okumus, F.; Hua, N. The role of utilitarian and hedonic values on users' continued usage intention in a mobile hotel booking environment. Int. J. Hosp. Manag. 2016, 57, 106-115. [CrossRef]

(C) 2019 by the authors. Licensee MDPI, Basel, Switzerland. This article is an open access article distributed under the terms and conditions of the Creative Commons Attribution (CC BY) license (http://creativecommons.org/licenses/by/4.0/). 